\title{
DEVELOPMENT OF COMMUNICATION PONDOK PESANTREN DARUL MUSYAWARAH KLUMOSARI BANJARAGUNG BANGSRI
}

\author{
Nurul Huda \\ Fadlun Nafis Foundation, Bangsri Jepara \\ Email: Hudaelthoyib@gmail.com \\ Siti Asiyah \\ Institut Pesantren Mathali'ul Falah Pati \\ Email: sitiasiyah@ipmafa.ac.id
}

\begin{abstract}
The development of communication is able to change the form of communication in boarding school. The development of the communication of Pesantren into a theme that needs to be examined because of the uniqueness and cultural peculiarities that exist in the pesantren usually difficult to receive the presence of development and progress of communication media. This type of research is a qualitative descriptive with a historical and phenomenological approach by analyzing the progress of communication that occurred in the Islamic boarding school. The results of this study showed that the development of communication in Pondok Pesantren Darul Musyawarah is characterized by the development phase of human communication that is in the area of Pesantren is started from the development of communication through writing media, print media, contemporary telecommunications media, and online media as a means of communication and information Pesantren. The development of communication in Pondok Pesantren Darul Musyawarah not only occurs in internal boarding but the communication between personal and group communication both the surrounding community, government, and other outside networks.
\end{abstract}

Keywords: Communication Development; Pesantren; Darul Musyawarah

\section{Introduction}

Human nature as a social creature is not separated from communication activities, ranging from waking up to sleeping back they are faced with various forms of communication, both the communication of interpersonal and group communication. Communication is the most important and vital thing for human beings (Nasrullah, 2014: 2) so that in the context of social relations between individuals and other individuals can interact and influence each other to achieve certain objectives.

Communicating skills are not the abilities we bring from birth and do not appear suddenly when we need them, but rather the skills we must learn and need to train like other skills (Supratikna, 1995: 12). Traditionally, communication is 
still considered to be an interdisciplinary field, interpersonal communication, for example, linked to studies on language, social cognition, and social psychology (Taufik, 2012: 35). So also in the Messtrenn, the application of communication is always practiced to work on the vision and mission of Pesantren.

Communication in Pesantren is often understood only the communication between Kiai, Ustadz, and students directly so that the communication process still looks fanatic and the same. Therefore, with the development of communication is able to make the communication actors dynamic and able to accept changes. Pesantren is a place where students study and deepen their religion. The uniqueness of Pesantren is able to attract researchers to study further as it relates to the communication that exists in the pesantren. Some of the components that exist in pesantren such as Kiai, caretaker, and students every day establish communication either directly or indirectly.

Communication of Pesantren attracted much attention by researchers, such as "Communication of the Da'wah Pesantren traditional" by Taufik Rahman, 2016. Rahman explained that Da'wah communication conducted in the boarding school Bustanul Widan can be done with interpersonal communication and group communication, as for the pattern of communication applied in Da'wah is with the pattern of communication action, interaction, and transactions (Rahman, 2016).

Next to the study "Communication pattern in Pesantren: Study of communication Model between Kiai, Ustadz, and Santri in Pondok Pesantren TMI Al-Amien Prenduan" by Rudi Hartono, 2016. Hartono explained that the model of the communication process is done between Kiai, Ustadz, and students using the communication model as Devito model and the Harold Dwight Laswell model so that both models are effectively applied in the communication model of Pesantren (Hartono: 2016) and tradition of communication in Pesantren by Ali Nurdin, 2015. Nurdin explained that the process of communication between the citizens of the Pesantren namely Kiai, Ustadz and students and traditions conducted in pesantren such as Sowan, Bandongan, Wetonan, Sorogan and Clasikal able to create the acculturation of value and culture in the students so that the process can be said as communication Intrabudaya Pesantren (Nurdin, 2015). From some of these research, authors intend to examine the development of communication pesantren 
whose objects are in boarding schools Darul Musyawarah Klumosari Banjaragung Bangsri Jepara.

This type of research is qualitative with a historical and phenomenological approach so as to generate descriptive data of subjects and behaviors observed both in writing and orally. In this study, the authors observe the development of communication that occurred in Pondok Pesantren Darul Musyawarah. The Data taken in this study by taking some relevant literature such as books, journals as well as past research was good with regard to the theory of boarding schools as well as theories about communication. The data sources taken by the authors include students, Pesantren, and caretaker Darul Musyawarah Pesantren.

The research focuses on the development of communication in the Islamic boarding school. The reason for taking research objects is because during this time the Pesantren still maintains old traditions and cultures so it is difficult to accept new things including developments in the field of communication. For that, the author focuses on researching the development of communication that is in Pondok Pesantren Darul Musyawarah Klumosari Banjaragung Bangsri Jepara.

\section{Basic Concepts of Communication Development}

Developments are all or many or grow (Departemen Pendidikan Nasional, 2007: 474). In other words, the development has a perfect meaning (about personal, mind, knowledge, and so on) (KBBI online). In the field of Communication Schramm (1988) Explains that developments are also named as a communication revolution that is part of a series of changes that have been ongoing in the history of human life so far. The communication revolution is one of the many revolutions that occur in various areas of human life (Nasution).

While the term communication is known in English Communication comes from the Latin word Communication, and is sourced from the word Communis which means the same. The same is meant by the same meaning (Effendy, 2006: 9). Communication is generally interpreted as relationships or activities relating to relationship problems, or also interpreted as exchanging opinions. Communication can also mean the contact relationship between individuals and both individual and group (Widjaja, 2000: 13). The Dedy Mulyana as Gerald R. Miller suggests communication as a situation that allows a source to transmit a message to the 
recipient consciously to influence the behavior of the recipient (Mulyana, 2005: 55). Onong Uchjana Effendy defines that communication is the process of delivering a message by a person to others to notify or to change attitudes, opinions, or behaviors, either directly orally, or indirectly through the media (Effendy, 2008: 5).

The development of communication started when people first knew the writing, characters are increasingly composed causing people to switch to write it through the traditional media until finally found a printing machine by Guterberg in Mainz (Germany) brought the progress of the communication process until today is able to use an increasingly sophisticated and new tools every time (Nasrullah, 2014:3-4).

Nasrullah as Everett M Rogers Records about the four phases of human communication development. These phases include the writing era, the printing era, the telecommunication era, and the Interactive communication era (Nasrullah, 2014:-4). First, in the writing era, it is evident that the era of communication began with writings that can be understood and pioneered by the Sumerians, this was further developed during the discovery of a printing machine by Gutenberg. Secondly, in the printing era, Rogers explained that in this phase of human communication is more advanced by utilizing print technology. Thirdly, the telecommunications of the era implicates long-distance communication (communication at a long distance), Rogers explains that the Telecommunication era is a rapidly growing era and enters the electronic era (telegraph) and triggers the Hali to develop newer technologies, such as radio and television (Rogers, 1994:29-30). Fourth is the interactive communication era which is the most contemporary era in which telecommunications occurs between two media that is related to the existence of computer (Nasrullah, 2014:6).

The development of communication is a combination of development and communication where communication is not only dotted in one place but can change both in terms of conditions during communication and media used in communication. Widjaja explained that communication developments can be characterized by the development of science and technology that produces communication and information technology products such as television, phone, 
and internet. From the explanation above, it can be concluded that the development of communication is increased progress in the communication between individuals and communications used using media.

\section{Study of Pondok Pesantren}

Boarding school (Pondok Pesantren) is a combination of two words namely Pondok and pesantren, each of which is a unity in carrying out a glorious vision. The term Pondok derives from the meaning of the dorm of the students or a place of residence made of bamboo, so the word pondok comes from Arabic that is funduq meaning hotel or hostel (Dhofier, 2011: 41). While the word Pesantren comes from the word santri, which with the prefix "PE" and the suffix "an" means the residence of the students. Johns argues that the term students is derived from the Tamil language, meaning teacher of the Koran, while Berg argues that the term students derived from Shastri which in Indian language means a person who knows the sacred books of Hindhu, or scholar of religious scriptures Hindhu. The word shastri derives from the word shastra meaning sacred books, religious books, or books on science. From the origins of the word students also many scholars argue that the school of Pesantren is essentially a religious education nation of Indonesia at the time of Islam Buddhist Hindhu named "Mandala" that is Islamized by the Kiai (Dhofier, 2011: 41).

Basically, Pondok Pesantren is liquid to teach Islam that is implemented with the system of Asrama or cottage with Kiai as the main central and mosque as the center of its learning. At the beginning, Pondok Pesantren Liquid Islamic teaching institutions are generally given in a nonclassical manner where a Kyai teaches the students based on books written in Arabic by the great scholars of the Middle Ages (12th century-16th century) (Arifin, 1993: 3). Pondok Pesantren is an educational institution that requires every student to follow the whole program of activities set in a school for 24 hours. Pondok pesantren provides dining facilities, teacher counselors who commonly referred to as kyai or ustad, lodging facilities, and other facilities (Santi, 2018: 214).

According to Moch Achyat as Hasani explained that the Pesantren in accordance with the essence and fundamental function of the institution that serves to form the students to fear Allah SWT (Ahmad, 2009: 184). While Yayan 
Rahayani revealed that in addition to giving about the teaching of Islam Islamic schools also give the noble values that exist in society (Rahayani, 2017: 114). Pesantren conducts intense management in order to form a good person, noble morality, become a person who fears God ALMIGHTY, follow the teachings of the Prophet Muhammad SAW, guided the Qur'an and Hadith, and follow the footsteps of the scholar's Salaf to build a high Islamic civilization. (Ahmad, 2009: 185). Pesantren until now is still a primadona of society because of the functions that run Pesantren (education function, social and da'wah) can be a unified system. Implementation of Pesantren Education (Mansur, 2013: 63).

Apart from being a hostel for the Koran and studying Islamic sciences, Pondok Pesantren is a source of information that never dried up for lovers of science and researchers who are trying to reduce the anatomic from sharing the discipline of knowledge began anthropology, politics, religion, and education. From the above harvest can be concluded that the boarding school is a place to study Islamic religion, with the non-classical system para Kiai educate students with morality and books Salaf from the Ulema'.

\section{Result and Discussion}

\section{Profile of Pondok Pesantren Darul Musyawarah}

Pondok Pesantren Darul Musyawarah is located on Jln. KH. Abdul Manan No. 5 Dukuh Klumosari RT 02 RW 05, village of Banjaragung Kecamatan Bangsri District Jepara. Geographically, Pondok Pesantren Darul Musyawarah is in the middle of residents ' settlements, from the junction of Jalan Raya Bangsri-Kelet Enter about 250 meters so that it is easily accessible by either public transportation or private vehicle.

Pondok Pesantren Darul Musyawarah was established in year 1970 CE by KH. Muhammad Afif Zubaidi, the establishment of this pesantren began from the building of the son's Pesantren and followed the founding of the Pesantren Women in 1994 CE with the study of the Book of Greetings and Tahfidzul Qur'an Program (Ni'matun, 2014: May 30). After the death of KH. Muhammad Afif Zubaidi on 20 March 2009 Pesantren Darul Musyawarah was forwarded by HJ. Ni'matun Afif and their children, namely KH. Burhanuddin, KH. Jauhar Hakimuddin, Hj. Nur Fauziyah, and KH. Fahdullah Labib. 
Islamic boarding school consists of three complexes in one environment, namely the complex of Pesantren Putri I was raised by $\mathrm{Hj}$. Delicious Afif, $\mathrm{KH}$. Burhanuddin and Hj. Nur Fauziyah. For the complex of Pesantren Princess II was served by Hj. Delicious Afif, KH. Jauhar Hakimuddin and Hj. Nur Hidayah. As for the complex III is a student boarding complex which is raised by $\mathrm{KH}$. Burhanuddin, $\mathrm{KH}$. Jauhar Hakimuddin and KH. Fahdlullah Labib (Fauziyah, 2014: August 17).

Pondok Pesantren Darul Musyawarah One of the Pesantren Salaf whose learning system is still traditional with a system of Bandongan (Soenhadji, 1993: 116), The Bandogan System is a teaching system of classical Islamic books, not governed by a programmatic syllabus, but in chapters listed on the book. This system is done by the teacher, Kyai to the students by translating the book then commented and explained by Kyai by Sorogan Method (Soenhadji, 1993: 38).The Sorogan method is the hardest part of the whole traditional educational method because it must demand patience, craft, obedience, and personal discipline of the students. The books used are written in a bare-letter without a letter of life.

While the other supporting the existence of Madrasah Diniyyah, Junior High School (SMP), Vocational High School (SMK), Jam'iyah Qurra ' wal Huffadz, Thariqah As-Shadziliyyah, assembly Ta'lim Wad Dhikir Asma'ul Husna, and Mujahadah Kubro (Hakimuddin, 2014: June 13).

\section{Communication Development of Pondok Pesantren Darul Musyawarah}

At the beginning of boarding schools Darul Musyawarah media used in communications still use traditional media such as the use of bulletin boards using whiteboards, call the students or in Javanese language (Nimbali) is still in a way of messaging with other students, information about pesantren using oral communication in word-of-mouth manner, communication students with parents by sending messages by mail, the use of the media bells in reminding the schedule of activities. More or less these past ten years, Pesantren Darul Musyawarah began to open and follow the age of the development by utilizing communication media as a supporter of communication and supporting activities in the pesantren.

As time goes by Pondok Pesantren Darul Musyawarah until now experiencing considerable communication development is quite significant both the development of interpersonal communication and development in the use of 
communication media. Communication developments in Darul Musyawarah boarding school include:

a. Development of communication through writing (The Writing Communication)

Communication activities conducted in Pondok Pesantren Darul Musyawarah Klumo Banjaragung Bangsri with communication (verbal communication) and non-verbal communication. Verbal communication practice is done by using verbal and written communication. Oral communication is communication that is done directly with face to face by citizens of Pesantren, while communication through writing is often written as a form of communication that requires other media such as by utilizing the bulletin board as a communication media, which in the written announcement of various information such as the schedule of activities, schedule of the students and other information relating to the activities that exist in the boarding school.

b. Communication Using the Printing

Communication in the area of Pondok Pesantren Darul Musyawarah, in addition to using verbal communication also utilizes the printing technology as a medium of communication and information to the students and society in general. The reason for the use of print media in the Pesantren area is to make communication and information easily obtained by students and society in general, easy to be accepted and understood by all students and the community, practical and effective. The use of print media in Pondok pesantren Darul Musyawarah, among others, rules around pesantren, printing students, making boarding school brochures, and making Pesantren calendar.

c. Communication with Electronic Media (Telecommunication)

The existence of electronic media in Pondok pesantren Darul Musyawarah can be utilized students to obtain information and entertainment. In addition to a variety of lessons about the science of students is also given the right to obtain information and adjustment of developments. The electronic media in the Pesantren is a television that can be watched on certain days and hours for students to receive information and also entertainment. In addition to television, in the Pesantren also provided phone for managers and senior 
students to be able to communicate with Kiai, nanny, caretaker and guardian students so that communication can run more effectively and efficiently. Komunikasi dengan Media Kontemporer (interactive Communication).

As stated by Nasrullah that the development of communication is characterized by the existence of telecommunications between two different media and facilitated with the existence of computers. At Pondok pesantren Darul Musyawarah provides computer devices as a facility of students for skill development and as a practical form to follow the development of science and technology even after the establishment of vocational secondary school (SMK) and Junior High School (SMP) Darul Musyawarah in Pesantren area is given additional computer facilities and Internet network as a means that support for communication, information and learning students.

d. Communication with Media Online.

Media Online is one means of communication and information online with access using the Internet or with other languages media-based multimedia. The development of communication in Pondok Pesantren Darul Musyawaraah also utilizes online media as a means of communication and information. The use of online media in Pesantren aims to make the presentation of information and communication that can be done quickly, easily accessed, and updated anytime and anywhere. As for the online media used in Pondok Pesantren Darul Musyawrah among them are websites, institution sites, blogs, and social media (Facebook and Instagram). Internet and online media facilities in the boarding school Darul Musyawarah also used as a facility to chase during the Covid-19 Pandemic (Nina: 2020, 05 June).

e. Education as a process of communication development

Education is a part of communication involving educators and students to engage in interactions and communications. Education in Pesantren Darul Musyawarah using the boarding system, in general, is with Bandongan and Sorogan system. In addition, in the year 2010 Yayasan Darul Musyawarah established a formal educational institution (SMK and Junior High School) which in the process of communication and learning in the school develops not only non-classical and in the sphere of pesantren but rather dig a lot of 
experience and many communicate with the community and outside the network.

f. Interpersonal communication and Group communication.

Communication that is done in Pesantren Darul Musyawarah not only occurs in the boarding area that only involves Kiai, Ustadz, caretaker and students but a lot of social and community authorities so that the pesantren also communicate with the community around (Community Communications) or outside the Pesantren, communication with the ranks of government (Government Communications) and communication with press Communication.

\section{Conclusion}

From the above exposure can be concluded that the development of communication in Pondok Pesantren Darul Musyawarah Klumosari Banjaragung Bangsri Jepara According to what is outlined Rulli Nasrullah as Rogers and A. W Widjaja that the development of communication can be seen from the phase of communication developments in the boarding area is able to undergo A writing ERA phase, the print era, telecommunication era, In addition, the development of boarding schools can be seen by accepting and utilizing communication and information technology by using the media as a means and supporting so that communication can be easier, faster and effective. The development of communication in Pondok Pesantren Darul Musyawarah not only occurs in internal boarding but the communication between personal and group communication both the surrounding community, government, and other outside networks. 


\section{Bibliograpy}

Ahmad, M. A. (2009) Mengapa harus Mondok di Pesantren. Pasuruan: Pustaka Sidogiri.

Arifin, I. (1993) Kepemimpinan Kyai Kasus Pondok Pesantren Tebuireng. Malang: Kalimasahada Press.

Departemen Pendidikan Nasional. (2007). Kamus Besar Bahasa Indonesia KBBI. Jakarta: Balai Pustaka.

Dhofier, Z. (2011). Tradisi Pesantren Studi Pandangan Hidup Kyai dan Visinya Mengenai Masa Depan Indonesia, Jakarta: LP3ES.

Effendy, O. U. (2006). Ilmu Komunikasi Teori dan Praktek. Bandung: PT Remaja Rosdakarya.

Effendy, O. U. (2008) Dinamika Komunikasi, Bandung: PT Remaja Rosdakarya

Hartono, R. (2016). Pola Komuniksi di Pesantren, Jurnal Dakwah dan Komunikasi Al-Balagh: IAIN Surakarta, - Vol. 1, No. 1, Januari - Juni

Interview results with Mrs. Hj. Nur Fauziyah, Pembina Pondok Pesantren Putri I, (Minggu, 17/08/2014), Pukul 14.08 WIB

Interview results with Mr. Jauhar Hakimuddin Afif, Pengasuh II Pondok Pesantren Putra, (Jum'at, 13/06/2014), Pukul 14.00 WIB

Interview results with Mrs. Hj. Ni'matun Istri dari K.H. Muhammad Afif Zubaidi (Jum'at, 30/05/2014), Pukul 21.08 WIB.

Interview results of Nina Santri Putri Kompleks I, (Jum'at, 05 Juni 2020). Pukul 10.00 WIB.

Kamus Besar Bahasa Indonesia (KBBi) versi online atau dalam jaringan (daring) http://kbbi.web.id/perkembangan.html diakses pada 13 Juni 2020 pukul 04.31 WIB.

Mansur, A. K. (2013). Konsistensi Pendidikan Pesantren: Antara Mengikuti Perubahan Dan Mempertahankan Tradisi, "JIE"Volume II No. 1 April 2013.

Masyhud, M. S., (2003). Manajemen Pondok Pesantren. Jakarta: Diva Pustaka.

Mulyana, D. (2005). Ilmu Komunikasi Suatu Pengantar. Bandung: PT Remaja Rosdakarya.

Nasution, Z. (2017). Modul 1 Latar Belakang Revolusi Teknologi Komunikasi, e-book http://repository.ut.ac.id/4482/1/SKOM4322-M1.pdf

Nurdin, A. (2015). Tradisi Komunikasi di Pesantren, KARSA: Jurnal Sosial dan Budaya KeIslaman Vol. 23 No. 2, Desember 2015: 275-294.

Rahayani, Y. (2017). Restrukturing dan Redesigning The Pesantren Toward an Effective Edducational Institution, TARBIYA: Journal of Education in Muslim Society, 4(2), 2017, 114-127.

Rahman, T. (2016). Komunikasi Dakwah Pesantren Tradisional, Ilmu Dakwah: Academic Journal for Homiletic Studies, Vol 10 No 2 | Juli-Des 
Development of Communication Pondok Pesantren ...

Santi, S. N., et. al. (2018). Communication Pattern of Kyai and Santri at TarbiyatulWildan Islamic Boarding school in Karawang Regenc.y, International Journal of Engineering \& Technology, 7 (3.25). p. 214-218.

Sonhadji, A., \& Hasan. M. T. (1993). Kepemimpinan Kyai Kasus pondok Pesantren Tebuireng. Malang: Kalimasahada Press.

Supratikna. (1995). Tinjauan Psikolgis Komunikasi Antar Pribadi, Yogyakarta: Kanisius.

Taufik, T. (2012). Komunikasi Islam dan Barat, Bandung: Pustaka Setia Bandung.

Widjaja. (2000). Ilmu Komunikasi Pengantar Studi, Jakarta: PT Rineka Cipta. 